\title{
Leadership Research of Taiwanese College Students' Learning Environment and Education Quality
}

\author{
Chia-Tsung Lee, Chia-Hui Lin, and Yin-Tsup Huang
}

\begin{abstract}
The current era of globalization has caused a phenomenon in business and educational organizations. Leadership has focused on broadening the globalized academic context (Dimmock \& Walker, 2000; Webber \& Robertson, 2003). The Taiwan Ministry of Education (MOE) launched the environment of the e-Future classroom to compete in globalization (MOE, 2011). A quantitative, research design explored the relationship between background demographic characteristics, transformational, and transactional leadership styles, learning environment, and education quality. A sample survey of 350 higher education students was developed with four components. The data collection included 292 returned surveys from 350 distributed, yielding an $83 \%$ return rate.
\end{abstract}

Index Terms-Leadership styles, learning environment, quality education.

\section{INTRODUCTION}

The current era of globalization has generated a phenomenon in business and educational organizations. Leadership has attempted to broaden the globalized academic context [1], [2]. The current worldwide transformation of universities has become common and some institutions have begun to resemble each other [3]. The increase of Taiwan universities has challenged academic leaders more than ever before in a fierce competitive higher education market [4], [5].

Taiwan higher education includes college and universities, graduate schools, and post-graduate programs. The Taiwan Ministry of Education (MOE) launched the environment of the e-Future classroom to compete with globalization [6]. Lewin [7] believed that all behaviors and experiences reflect a person's environment. Constructive learning environments are learner-centered, so students become active participants in education areas. Therefore, in the learning centered environment, students focus on learning rather than teaching [8]. College institutions have a serious battle because of their uneven distribution of resources.

Different leadership styles might influence the learning environment and education quality of various colleges in Taiwan. This study examines the higher educational leadership styles, learning environment, and educational quality in Taiwan.

Manuscript received October 27, 2011; revised November 30, 2011

C. $-\mathrm{T}$. Lee is with National Taichung University of Education, Taiwan(e-mail: leect@ntcu.edu.tw).

C. -H. Lin and Y. - T. Huang are with Toko University, Taiwan (e-mail: Tinalin26@hotmail.com; 2009hm02@mail.toko.edu.tw).

\section{Literature REVIEW AND HYPOTHESES DEVELOPMENT}

Leadership has been defined in various ways in the past 60 years. "Academic leadership is one of the most important factors when initiating and implementing institutional development or change process" [5]. Leadership is "a process whereby an individual influences a group of individuals to achieve a common goal" [9].

\section{A. Transactional and Transformational Leadership}

Transformational leadership is a process that motivates and inspires teams to be effective and efficient. Leaders have high visibility and commend getting a job done [10]. The role of transformational leadership needs the challenge of changing times [11]. Bass and Avloio [12] suggested five component of transformational leadership: a) idealized influence or attributed charisma; b) idealized influence or behavioral charisma; c) inspirational motivation; d) intellectual stimulation; and e) individualized consideration

Transactional leadership confirms the relationship between performance and reward and gives leaders the opportunity to lead the group and to accomplish goals in exchange for something else [10]. Transactional leadership has remained as the organizational model [11]. Bass and Avloio [12] suggested three components of a) contingent reward; b) management by exception (passive); and c) management by exception (active).

Lewin [13] introduced his seminal theory on the influence of leadership styles based on the leader's decision-making behavior. This theory identifies three major constructs of authoritarian, democratic, and Laissez-fair leadership. Similar to Lewin's [13] model, the theory has been revised and adapted to the behavior leadership model [14]. John Adair [15] developed an action-centered leadership model depicting the direct and indirect relationship among task, individual, and team concepts, which continues to be examined today [11]. James MacGregor Burns [16] was the first to apply his concept to transformational leadership. Studies by Tichy and Devanna [17] described the hybrid nature of transformation. Bass and Avloio [12] created the four dimensions of transformational leadership, transactional leadership, non-transactional leadership, and leadership outcomes in the Multifactor Leadership Questionnaire (MLQ).

\section{B. Learning Environment}

The learning environment field has undergone 30 years of diversification and internationalization [18]. Fraser [18] described that classroom environment quality plays a significant role in student learning. International research in this field involves the assessment, conceptualization, and 
investigation of perceptions of the classroom environment [19], [20].

Jonassen [21] proposed a model for designing constructivist learning environments and introduced three components in constructivist learning environments: problem, question, or project as the focus of the environment. Hannafin, Land, and Oliver [22] mentioned, "Learning environments are typically constructivist in nature, engaging learners in "sense-making" or reasoning about extensive resource sets". This theory identifies four major constructs or components: an enabling context, resources, a set of tools, and scaffolds.

Jonassen [23] identified the following design goals for constructivist learning environments:

- Negotiation, rather than imposition, of goals and objectives;

- Task analysis consideration be given to appropriate interpretations and provision of intellectual tools necessary to learners for constructing knowledge;

- Promotion of multiple perspectives of reality through these tools and within the environment;

- Provision of generative, mental construction "tool kits" embedded in relevant learning;

- Environments that facilitate knowledge construction by learners; and

- Evaluation should become more goal-free and reflective .

Fig. 1 presents Jonassen's conceptualization of design elements for a constructivist-learning environment, which focuses on "keeping students active, constructive, collaborative, intentional, complex, contextual, conversational, and reflective" [24].

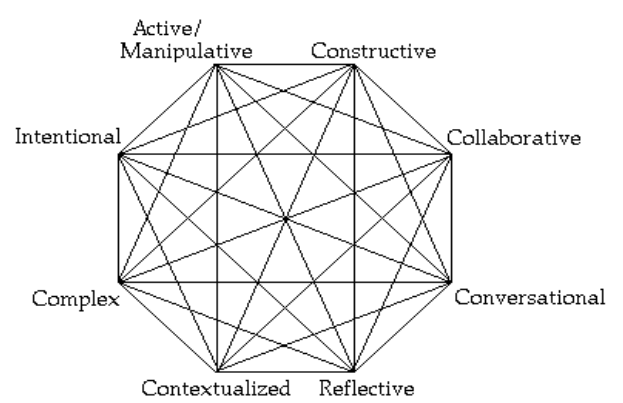

Fig. 1. Designing a constructivist learning environment (adopted from Jonassen's 1999).

\section{Quality of Education}

Cheng and Tam [25] defined education quality as "the character of the set of elements in the input, process, and output of the education system that provides services that completely satisfy both internal and external strategic constituencies by meeting their explicit and implicit expectations". Tam and Chen [25] proposed seven models to evaluate the concept of education quality : (1) goal and specification model; (2) resource-input model; (3) process model; (4) satisfaction model; (5) legitimacy model; (6) absence of problems model; and (7) organizational learning model. The evaluation of the process model of quality education includes leadership, classroom climate, social interaction, participation, experiences, and learning activities. Educational quality contains various components: effectiveness, efficiency, equality, relevance, and sustainability [26].

\section{Hypothesis}

H1: Learning environment and education quality have statistical difference on teachers' transformational and transactional leadership styles.

H2: A background demographic characteristic with type of school (public school, private school) has significant explanatory variables of perceived transformational and transactional leadership, learning environment, and education quality.

H3: Teachers' transformational leadership style is statistically significant for learning environment.

H4: Teachers' transactional leadership style is statistically significant for education quality.

H5: Teachers' transformational leadership styles (idealized attributes, idealized behaviors, inspirational motivation, intellectual stimulation, and individualized consideration) and transactional leadership styles (contingent reward, active management by exception, passive management by exception) are significant explanatory variables of perceived learning environment (student cohesiveness, teacher support, involvement, order and organization, task orientation, cooperation, equity).

H5a:Teachers' transformational leadership styles and transactional leadership styles are significant explanatory variables of perceived learning environment with student cohesiveness.

H5b:Teachers' transformational leadership styles and transactional leadership styles are significant explanatory variables of perceived learning environment with teacher support.

H5c: Teachers' transformational leadership styles and transactional leadership styles are significant explanatory variables of perceived learning environment with involvement.

H5d:Teachers' transformational leadership styles and transactional leadership styles are significant explanatory variables of perceived learning environment with order and organization.

H5e:Teachers' transformational leadership styles and transactional leadership styles are significant explanatory variables of perceived learning environment with task orientation.

H5f:Teachers' transformational leadership styles and transactional leadership styles are significant explanatory variables of perceived learning environment with cooperation.

H5g:Teachers' transformational leadership styles and transactional leadership styles are significant explanatory variables of perceived learning environment with equity.

\section{Methodology}

\section{A. Research Design}

A non-experimental, quantitative, SPSS 17.0, research 
design explored the relationship of background demographic characteristics, transformational and transactional leadership, learning environment, and education quality.

\section{B. Population and Sampling Plan \\ C. Target Population}

According to the Taiwan Ministry of Education Department of Statistics [6], there are nine colleges and universities in Taichung City and County and three colleges and universities in Chiayi City and County. Target populations were 177 college students in Taiwan. The convenience sample included students enrolled in National Taichung University of Education, Ling Tung University, and Toko University in Taiwan.

\section{Sampling Plan}

The entire accessible population was invited to participate in the study. However, the final data-producing sample was self-selected depending on those who agreed to participate in the study.

\section{E. Instrumentation}

The instrument used in this study includes four parts: For the surveys, (1) Background Demographic Characteristics were developed by the researchers, (2) transformational and transactional leadership-measured by two of the five factors of the Multifactor Leadership Questionnaire (MLQ Form $5 x$-short), was developed by Bass and Avolio [12], (3) learning environment was measured by seven factors of What Is Happening In This Class? (WIHIC), developed by Fraser, Fisher, and McRobbie [27], (4) quality of education was measured by four of the six factors of Instructions for Delphi Survey, developed by Dalkey [28].

\section{RESULT}

\section{A. MANOVA Analysis}

In Hypothesis 1, learning environment and quality education have statistical difference for teachers' transformational and transactional leadership style.

TABLE I: MANOVA ANALYSIS OF TRANSFORMATION AND TRANSACTIONAL LEADERSHIP, LEARNING ENVIRONMENT, AND QUALITY OF

\begin{tabular}{|c|c|c|c|}
\hline \multicolumn{4}{|c|}{ EDUCATION } \\
\hline Variables & $\mathrm{df}$ & SSCP & Sig. \\
\hline Learning & \multirow{2}{*}{4} & [6.419 5.925] & .050 \\
\hline Environment & & [ 5.9259 .230 ] & .044 \\
\hline \multirow{2}{*}{ Quality Education } & \multirow{2}{*}{4} & {$\left[\begin{array}{ll}.492 & -.554\end{array}\right]$} & .004 \\
\hline & & {$\left[\begin{array}{ll}-.554 & 4.068\end{array}\right]$} & .020 \\
\hline Learning & \multirow{2}{*}{9} & {$[3.121 .446]$} & .025 \\
\hline $\begin{array}{l}\text { Environment * } \\
\text { Quality Education }\end{array}$ & & {$\left[\begin{array}{ll}.446 & 8.628\end{array}\right]$} & .041 \\
\hline \multirow{2}{*}{ Error } & \multirow{2}{*}{18} & {$\left[\begin{array}{lll}121.523 & 67.324\end{array}\right]$} & \\
\hline & & {$\left[\begin{array}{ll}67.324 & 199.267\end{array}\right]$} & \\
\hline
\end{tabular}

\section{B. Logistic Regression Analysis}

In Hypothesis 2, a background demographic characteristic with the type of school (public school, private school) has significant explanatory variables of perceived transformational and transactional leadership, learning environment, and quality of education.

TABLE II: LOGISTIC REGRESSION ANALYSIS WITH A BACKGROUND DEMOGRAPHIC CHARACTERISTIC OF TyPE OF SCHOOL (PubliC SCHOOL, PRIVATE SCHOOL), TRANSFORMATIONAL AND TRANSACTIONAL LEADERSHIP, LEARNING ENVIRONMENT, AND QUALITY OF EDUCATION

\begin{tabular}{|c|c|c|c|c|c|c|c|}
\hline & & B & S.E. & Wald & $\begin{array}{l}\text { d } \\
\text { f. }\end{array}$ & Sig. & $\operatorname{Exp}(B)$ \\
\hline $\begin{array}{c}\text { Step } \\
0\end{array}$ & $\begin{array}{c}\text { Constan } \\
\mathrm{t}\end{array}$ & 1.417 & .148 & 92.048 & 1 & .000 & 4.123 \\
\hline
\end{tabular}

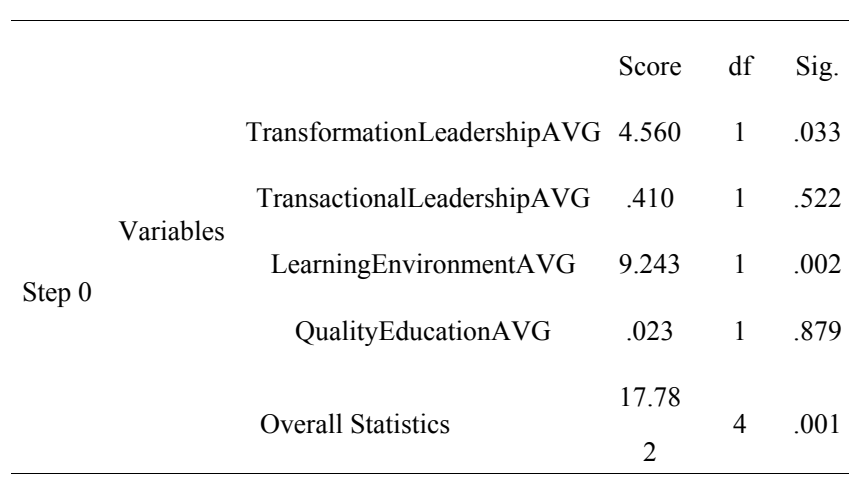

\section{One-Way ANOVA Analysis}

In Hypothesis 3, teachers' transformational leadership style has statistical significance for learning environment.

TABLE III: ANOVA ANALYSIS OF TRANSFORMATIONAL LEADERSHIP STYLE AND LEARNING ENVIRONMENT

\begin{tabular}{cccccc}
\hline \multicolumn{5}{c}{ STYLE AND LEARNING ENVIRONMENT } \\
& $\begin{array}{c}\text { Sum of } \\
\text { Squares }\end{array}$ & df & $\begin{array}{c}\text { Mean } \\
\text { Square }\end{array}$ & F & Sig. \\
\hline Between Groups & 18.442 & 4 & 4.610 & 7.720 & .000 \\
Within Groups & 171.394 & 287 & .594 & & \\
Total & 189.836 & 291 & & & \\
\hline
\end{tabular}

a. Predictors: (Constant), Transformational leadership style

b. Dependent Variable: Learning environment

In Hypothesis 4, teachers' transformational leadership style has no statistical significance for quality education.

TABLE IV: ANOVA ANALYSIS OF TRANSACTIONAL LEADERSHIP STYLE AND QUALITY EDUCATION

\begin{tabular}{ccccccc}
\hline & $\begin{array}{c}\text { Sum of } \\
\text { Squares }\end{array}$ & df & Mean & & \\
& & Square & & Sig. \\
Between Group & 4.557 & 4 & 1.139 & 2.036 & .089 \\
Residual & 160.608 & 287 & .560 & & \\
Total & 165.164 & 291 & & & \\
\hline
\end{tabular}

a. Predictors: (Constant), Transactional leadership style

b. Dependent Variable: Quality education

\section{Two-Way ANOVA Analysis}

In Hypothesis 5a, 5b, 5c, 5d, 5f, and 5g, transformational leadership styles and transactional leadership styles have no significant explanatory variables of perceived learning environment with student cohesiveness, teacher support, 
involvement, order and organization, cooperation, and equity.

In Hypothesis 5e, transformational leadership styles and transactional leadership styles have a significant explanatory variable of perceived learning environment with task orientation.

\section{E. Reliability Analysis}

Cronbach's alphas and item analyses were conducted on all variables: alphas $=.887$.

TABLE V: CRONBACH ALPHA COEFFICIENTS OF TRANSFORMATIONAL LEADERSHIP STYLE, TRANSACTIONAL LEADERSHIP STYLE, LEARNING ENVIRONMENT AND QUALITY EDUCATION

\begin{tabular}{ccc}
\hline Cronbach's Alpha & $\begin{array}{c}\text { Cronbach's Alpha Based on Standardized } \\
\text { Items }\end{array}$ & N of Items \\
\hline .887 & .887 & 13 \\
\hline
\end{tabular}

\section{F. Factor Analysis for Construct Validity}

TABLE VI shows the results of KMO and Bartlett's test of sphericity. The value of KMO was 0.872 .

TABLE VI: KMO AND BARTLETT'S TEST RESULTS ON TRANSFORMATIONAL LEADERSHIP STYLE, TRANSACTIONAL LEADERSHIP STYLE, LEARNING ENVIRONMENT, AND QUALITY EDUCATION

\begin{tabular}{ccc}
\hline \multicolumn{2}{c}{ Kaiser-Meyer-Olkin Measure of Sampling Adequacy } & .872 \\
\hline Bartlett's Test of Sphericity & Approx. Chi-Square & 1758.171 \\
& $d f$ & 78 \\
& Sig. & .000 \\
\hline
\end{tabular}

TABLE VII: EXTRACTION SUMS OF SQUARED LOADINGS ON TRANSFORMATIONAL LEADERSHIP STYLE, TRANSACTIONAL LEADERSHIP STYLE, LEARNING ENVIRONMENT, AND QUALITY EDUCATION

\begin{tabular}{|c|c|c|c|c|c|c|}
\hline \multirow{2}{*}{$\begin{array}{c}\text { Com } \\
\text { pone } \\
\text { nt }\end{array}$} & \multicolumn{3}{|c|}{ Initial Eigenvalues } & \multicolumn{3}{|c|}{$\begin{array}{c}\text { Extraction Sums of Squared } \\
\text { Loadings }\end{array}$} \\
\hline & Total & $\begin{array}{c}\% \text { of } \\
\text { Variance }\end{array}$ & $\begin{array}{c}\text { Cumulative } \\
\%\end{array}$ & Total & $\begin{array}{c}\% \text { of } \\
\text { Variance }\end{array}$ & $\begin{array}{c}\text { Cumulative } \\
\%\end{array}$ \\
\hline 1 & 5.691 & 43.776 & 43.776 & 5.691 & 43.776 & 43.776 \\
\hline 2 & 1.488 & 11.447 & 55.223 & 1.488 & 11.447 & 55.223 \\
\hline 3 & 1.250 & 9.615 & 64.838 & 1.250 & 9.615 & 64.838 \\
\hline 4 & .776 & 5.967 & 70.805 & & & \\
\hline 5 & .597 & 4.595 & 75.400 & & & \\
\hline 6 & .556 & 4.275 & 79.675 & & & \\
\hline 7 & .524 & 4.032 & 83.707 & & & \\
\hline 8 & .480 & 3.690 & 87.397 & & & \\
\hline 9 & .459 & 3.529 & 90.926 & & & \\
\hline 10 & .383 & 2.947 & 93.874 & & & \\
\hline 11 & .358 & 2.754 & 96.628 & & & \\
\hline 12 & .246 & 1.895 & 98.523 & & & \\
\hline 13 & .192 & 1.477 & 100.000 & & & \\
\hline
\end{tabular}

TABLE VII indicates that five factor values were larger than one after varimax rotation was extracted, which accounted for almost $65 \%$ of total variance.

\section{CONCLUSIONS}

This study explored the relationship among demographic characteristics, teachers' transformational leadership style, teachers' transactional leadership style, learning environment, and education quality among 350 randomly selected Taiwan higher education college students. The survey instruments were used in three colleges for data collection. In total, 292 survey questionnaires were returned, with a return rate of $83 \%$.

Analysis of the research results found a significant relationship among learning environment, quality education, and teachers' transformational and transactional leadership styles. A background demographic characteristic with type of school (public school, private school) was also statistically significant for transformational and transactional leadership, learning environment, and quality of education. Teachers' transformational leadership style was significant for learning environment. Transformational leadership styles and transactional leadership styles did not have a significant explanatory variable of perceived learning environment with task orientation.

However, teachers' transformational leadership style showed no statistical significance for quality education. Transformational leadership styles and transactional leadership styles did not have significant explanatory variables of perceived learning environment with student cohesiveness, teacher support, involvement, order and organization, cooperation, and equity.

\section{PRACTICAL IMPLIACATIONS}

Leadership styles do play an important role for learning environment and education quality in higher education. The findings of this study might benefit Taiwan higher education organizations, companies, and educational departments. These institutions could focus on educators' leadership styles to improve the learning environment and education quality.

\section{FUtURE STUDY AND LIMATIONS}

This study was limited to Taiwan undergraduate students within three colleges. The study only focused on a quantitative study with 350 students. Fifteen minutes of answering a survey might not be enough for students fill in and consider all of the questionnaires. Future studies might adopt more methods and explore various variables. The accessible population should be enlarged to strengthen the generalizability of the study.

\section{ACKNOWLEDGMENT}

Thanks for all of the co-authors who cooperate for this research article. I do really enjoy being a teacher and researcher as well. 


\section{REFERENCES}

[1] C. Dimmock and A. Walker, "Developing comparative and international educational leadership and management: A cross-cultural model," Sch. Leader. Manage. vol. 20, no. 2, pp.137-141, 2000.

[2] C. F. Webber, J. M. Robertson, "Developing an international partnership for tomorrow's educational leaders," Int. Stud. Educ. Admin. vol.31, no. 1, pp. 15-31, 2003.

[3] S. Marginson, "Global Comparisons and the University Knowledge Economy," In Portnoi, V.D., Rust, V. D. \& Bagley, S. S. (Ed.) Higher education, policy, and the global competition phenomenon. New York, NY: Palgrave Macmillan, 2010.

[4] J. K. Chen and I. S. Chen, "Personal traits and leadership styles of Taiwan's higher educational institutions in innovative operations," Journal of American Academy of Business, Cambridge, vol.12, no.2, pp. 145-150, 2008. Retrieved July 17, 2011, from ProQuest database.

[5] T. Panagiotis and D. Dimitra, "Leadership and service quality in higher education: The case of the technological educational institute of Larissa. International," Journal of Quality and Service Sciences, vol.1, no. 3, PP 294-310, 2009.

[6] Ministry of Education of Republic of China. (2011). Education in Taiwan. Retrieved July 15, 2011, from http://english.education.edu.tw/public/Attachment/011114493771.pdf

[7] K. Lewin, Principles of topological psychology. New York: McGraw-Hill, 1936.

[8] S. Reushle, 2006, A framework for designing higher education e-learning environments. Retrieved 26 October 2011, from http://knowledgegarden.usq.edu.au/tiki-index.php?page_id:630

[9] P. G. Northouse, 2007, Leadership theory and practice (4th ed.). Thousand Oaks: SAGE Publications.

[10] J. M. Burn, 1978, Leadership, New York: Harper and Row.

[11] R. Bolden, J. Gosling, A. Marturano, and P. Dennison, "A review of leadership theory and competency frameworks," Centre of Leadership Studies, no. 3, pp. 1-44, 2003.

[12] B. M. Bass, B. J. Avolio, D. I. Jung, and Y. Berson, "Predicting unit performance by assessing transformational and transactional leadership," Journal of Applied Psychology, vol. 88, no. 2,pp. 207-218, 2003.

[13] K. Lewin, R. Lippit, and R. K. White, "Patterns of aggressive behavior in experimentally created social climates," Journal of Social Psychology, vol.10, pp. 271-301, 1939.

[14] R. Blake and J. Mouton, 1964, The Managerial Grid: The Key to Leadership Excellence. Houston: Gulf Publishing Co.

[15] J. Adair, 1973, Action-Centred Leadership. New York,:McGraw-Hill.

[16] K. James and J. Burgoyne, 2001, Leadership Development: Best practice guide for organisations. London: Council for Excellence in Management and Leadership.

[17] N. Tichy and M. Devanna, 1986, Transformational Leadership. New York: Wiley. United States Office of Personnel Management - Senior Executive Service Leadership Competencies.

[18] B. J. Fraser, 1998a, "Science learning environments: Assessment, effects and determinants. In B.J. Fraser \& K.G. Tobin (Eds.),"
International handbook of science education (pp. 527-564). Dordrecht, The Netherlands: Kluwer.

[19] B. J. Fraser, 1994, Research on classroom and school climate. In D.L. Gabel (Ed.), Handbook of research on science teaching and learning (pp. 493-541). New York: Macmillan.

[20] B. J. Fraser and H. J. Walberg (Eds.), 1991, Educational environments: Evaluation, antecedents and consequences. Oxford, England: Pergamon Press.

[21] D. H. Jonassen, 1999, "Designing constructivist learning environments. In C. M. Reigeluth (Ed.)," Instructional design theories and models: A new paradigm of instructional theory, volume II, pp. 215-239. Mahwah, NJ: Lawrence Erlbaum Associates.

[22] M. Hannafin, S. Land, and K. Oliver, 1999, Open learning environments: Foundations, methods, and models. In C. Reigeluth (Ed.), Instructional Design Theories and Models (pp. 115-140). Mahwah, NJ: Lawrence Erlbaum Associates.

[23] D. H. Jonassen, "Evaluating Constructivist Learning," Educational Technology, vol.31, no.9, pp. 28-33, 1991.

[24] Berglund Center for Internet Studies, 2002, Education and values: Constructivist foundations of teaching and learning. Retrieved July 26, 2011, from http://education.ed.pacificu.edu/aacu/workshop/constructivism.html

[25] Y. C. Cheng and M. Tam, "Multi-models of quality in education," Quality Assurance in Education, vol. 5, no.1,pp. 22-31, 1997.

[26] A. M. Barrett, R. C. Duggan, J. Lowe, J. Nikel, and E. Ukpo, 2006, The concept of quality in education: A review of the international literature on the concept of quality in education. Retrieved July 29, 2011, from http://www.edqual.org/publications/workingpaper/edqualwp3.pdf

[27] B. J. Fraser, D. L. Fisher, and C. J. McRobbie, 1996, Development, validation and use of personal and class forms of a new classroom environment instrument. Paper presented at the annual meeting of the American Educational Research Association, New York.

[28] N. C. Dalkey, 1969, The Delphi method: An experimental study of group opinion, Santa Monica, CA: Rand Corporation.

Chia-Tsung Lee is an assistant professor who works for the National Taichung University of Education. His research interests include comparative education and higher education.

E-mail:leect@ntcu.edu.tw

Chia-Hui Lin. was born in Taiwan and studied the Ph.D for the Global Leadership, with a specialization in Educational Leadership in Lynn University, Florida, United States. Her research interests include computer-assisted language learning (CALL), higher education, and language learning

The current job that she works for the Toko University and to be the assistant professor in Taiwan.E-mail:Tinalin26@hotmail.com

Yin Tsup Huang is an assistant professor and director in the Toko University, Taiwan (e-mail: 2009hm02@mail.toko.edu.tw). 